\title{
The Application of ITS-2 Model for Flood Hydrograph Simulation in Large-Size Rainforest Watershed, Indonesia
}

\author{
I Gede Tunas' \\ 1 Department of Civil Engineering, Faculty of Engineering, Universitas Tadulako, Palu-Central Sulawesi, 94117, \\ Indonesia \\ e-mail: tunasw@yahoo.com
}

\begin{abstract}
Nowadays, the increasing intensity of extreme rainfall and changes in land use have triggered massive floods in various regions of Indonesia. The changes in the characteristics of these two parameters cause an increase in the peak and duration of the flood over time. Peak and duration of flood estimation might be very useful for the national and local government because it is closely related to the effectiveness of prevention and mitigation plan in the future. A hydrograph-based model constitutes one approach to estimating them simultaneously. The objective of this research is to examine the application of ITS-2 - a synthetic unit hydrograph (SUH) model which was developed at Sepuluh Nopember Institute of Technology (ITS) in 2017 - for estimating the peak flood discharge as a basis for planning disaster mitigation programs. This study was carried out by testing the reliability of the ITS-2 Model using the Nash-Sutcliffe Efficiency (NSE) indicator by comparing the measured unit hydrograph and synthetic unit hydrograph derived using the model, optimizing the parameters of the model, and then analyzing the transformation of rainfall-flood discharge in the Gumbasa Watershed, one of the major watersheds in Central Sulawesi Province, Indonesia. This catchment is part of the Palu watershed, which is largely a tropical rainforest conservation area known as the Lore Lindu National Park. The input model is based on the design rainfall with a certain return period using the frequency analysis where the data was obtained from the rainfall stations in the study area. The results of the research showed that the performance of the ITS- 2 model was still very good with the NSE above $80 \%$. The difference in the peak discharge of these two unit hydrographs is relatively low, with a deviation below $10 \%$. The optimal values of the ITS-2 Model parameter coefficients consisting of $C_{1}, C_{2}$, and $C_{3}$ were achieved at $1.29,0.33$ and 1.88 , respectively. The results of the hydrograph analysis based on a 1-year to 100 -year return period indicate that peak flood discharge ranges from $100 \mathrm{~m}^{3} / \mathrm{sec}$ to $550 \mathrm{~m}^{3} / \mathrm{sec}$. From a series of analyses and tests that have been conducted in the previous and current research, it can be concluded that the ITS-2 Model can be applied to various watershed sizes, especially in Indonesia.
\end{abstract}

Keywords: flood management, hydrology model, river basin, peak flow, tropical area, Institut Teknologi Sepuluh Nopember.

\section{INTRODUCTION}

Indonesia is one of the nations in Asia that is highly vulnerable to various disasters, especially floods (Asdak et al., 2018). This disaster has occurred simultaneously in various regions in Indonesia as a consequence of the location of tropical island countries between the Indian Ocean and the Pacific Ocean, with an area of the ocean larger than the land area. One of the main causes of the increasing potential intensity of this disaster is climate change (Asdak et al., 2018 and Akter et al., 2018). Global warming is considered the main trigger of climate change, with the main characteristic of extreme rainfall with high frequency and intensity (Huang et al., 2018 and Samu and Kentel, 2018). La Nina and El Nino, as characteristics phenomena related to climate change and the effects of global warming, also play a role in the formation of extreme rainfall (Gao et al., 2018). The increase in extreme rainfall intensity in Indonesia has triggered massive floods in various regions such as Java, Sumatra, Kalimantan, Sulawesi and Papua. Indonesian National Board 
for Disaster Management-BNPB (2019) reported that the last flood in mid-January 2019, which occurred almost simultaneously in South-East Aceh and Nort Aceh (The western part of Indonesia), Gowa, Janeponto and Makassar (South Sulawesi), Sigi and Donggala (Central Sulawesi), Tapin and Balangan (South Kalimantan), and Tolikara and Jayapura (Papua), caused very serious social, economic and environmental impacts.

Along with the increasing potential of floods in recent times, BNPB has developed an integrated mitigation program both pre-disaster and post-disaster, one of which is the estimated peak and duration of the flood. These parameters must be carefully and accurately determined because they are closely related to the effectiveness of the disaster mitigation programs (Matteo et al., 2019). Nowadays, various methods have been developed to estimate the peak of flooding with various advantages and limitations (Grimaldi et al., 2012; Chen et al., 2017; and Li et al., 2017). The technique that is able to simultaneously estimate the peak and duration of floods is a hydrograph-based method, one of which is a synthetic unit hydrograph model. The peak of the flood can be determined from the top of the hydrograph, while the duration of the flood can be derived from the basic time of the hydrograph. In addition, this model is very effective when applied to unmeasured watersheds or the watershed with limited data. The peak of the flood can be predicted well only with information on the maximum rainfall in the past and the current morphometric parameters of the watershed (Javaheri and Sebens, 2014). However, the validity of this model is very dependent on the physical condition of the watershed where this model will be applied.

ITS-2 is the latest synthetic unit hydrograph model developed at the Sepuluh Nopember Institute of Technology (ITS) in 2017 (Tunas and Anwar, 2018 and Tunas et al., 2018).This model is the development of the previous similar models such as Snyder, Nakayasu and GAMA I, which have been widely applied in Indonesia (Kusumastuti et al., 2012 and Safarina et al., 2012), especially for designing hydraulic structures such as weirs, dams and flood canals. The main characteristic of this model is that the parameters are a combination of fractal characteristics and watershed morphometry and the hydrograph curve is a simple single equation. This model has also been used primarily to estimate the design flood in small and medium sized catchments in several watersheds in Indonesia. Ansory et al. (2017) conducted a design flood analysis in the Way Apu watershed - Buru Island - Maluku using the ITS-2 Model as the basis for designing dams for water supply, irrigation and hydropower. Due to the limitations of hydrometric data, the performance of the model was not tested, but only compared with the results of analysis involving other models such as Snyder, Nakayasu and ITB. In 2018, Tunas and Anwar (2018) examined the performance of the ITS-2 Model in the Telen watershed, one of the medium-sized measured watersheds on the island of Borneo. The results of the analysis showed that the ITS-2 Model indicates good performance, even though it is applied to watersheds with different characteristics.

The Gumbasa Watershed is one of the important sub-watersheds in Indonesia, especially in the Central Sulawesi Province. More than one third of the catchment area is part of the Palu watershed, one of the largest watersheds in Central Sulawesi that supplies raw water and irrigation needs in the Palu Valley. Besides being part of the Palu watershed, this catchment is also important because most of its area is a conservation forest known as Lore Lindu National Park (TNLL). However, the development of the population has caused major changes in this watershed, especially related to the land use. The opening of new land up to the conservation area for agriculture, plantations, mining and settlements has resulted in a decrease in the carrying capacity of the watershed, especially for water conservation. The changes in the physical properties of the watershed that occur simultaneously with climate change have triggered repeated flood disasters in the downstream areas of this watershed. The large flood events recorded in the BNPB document occurred in 1996, 2010, 2014, 2016 and 2018, especially in the Palolo Valley. Supervision and restrictions on the conversion of new land by the Forestry Service of Central Sulawesi Province and the TNLL Office have not shown significant results in reducing the potential for floods in the region.

The studies on forest conservation and the impact of climate change in the Gumbasa Watershed have been carried out by previous researchers. Since 2001, intensive research has been performed by the scientists from the Stability of Rain Forest Margin (STORMA), a collaborative research project between four universities: University of Göttingen (Germany), Kassel University (Germany), Bogor Agricultural University (Indonesia) and 
Tadulako University (Indonesia). Leemhuis and Gerold (2006) analyzed the water resource availability in the watersheds due to the warm phase of ENSO (El Nino Southern Oscillation) events. The results of the analysis showed that the annual discharge has declined under warm phase ENSO conditions. As a continuation of the study, Leemhuis et al. (2007) and Gerold and Leemhuis (2008) studied the impact of land use change of the watershed on the flow variability. The main result of the research indicated that the land use conversion has increased the river discharge. However, from a series of studies conducted in this watershed, no one has reviewed the peak flood discharge for mitigation programs. Therefore, this research is important and will contribute to preparing basic data for flood mitigation activities in the Gumbasa Watershed and surrounding areas using ITS-2 as a model for analysis.

\section{MATERIAL AND METHODS}

\section{Study Region}

The Gumbasa Watershed - one of the large rainforest watershed in Indonesia by area and discharge - located in Central Sulawesi Province, has a total area of approximately $1,306 \mathrm{~km}^{2}$ (Figure 1a-d). The watershed is geographically situated in tropical region between longitudes $119^{\circ} 56^{\prime} 36.58^{\prime \prime} \mathrm{E}-120^{\circ} 18^{\prime} 52.88^{\prime \prime} \mathrm{E}$ and latitudes $1^{\circ} 1$ '10.18'S-1 ${ }^{\circ} 30^{\prime} 2.24^{\prime \prime} \mathrm{S}$ and is characterized by a topography ranging from $99 \mathrm{~m}$ a.s.l. to 2,491 $\mathrm{m}$ a.s.l. The Gumbasa River is the major tributary of the Palu River and it originates from the Napu Mountain passing through the famous Lindu Lake in the southern side, the Nokilalaki Mountain in the middle part and the Palolo Valley in the northern side of the watershed before draining into the Palu River.

On the basis of the geomorphology structure, the study area consists of valleys and mountainous region. There are two valley present in the region: Palolo and Lindu Valleys. The latter covers a wellknown Lindu Lake with an area of $34.88 \mathrm{~km}^{2}$ or about one-fortieth of the watershed which is one of the main source drainage of the Gumbasa River. The area of the mountainous region is greater than the valley which covers more than $70 \%$ of the total area of the catchment. It can be divided in two categories: the boundary of the catchment which consists of Kulawi, Napu and Palolo Mountains and the mountain that separates the Palolo and Lindu Valleys, called Nokilalaki Mountain. Most of the watershed area is the part of protected rainforest, known as Lore Lindu National Park (TNLL) which covers an area of roughly $765.1 \mathrm{~km}^{2}$. The park is one large protected region in Indonesia to preserve and conserve the diversity of animals and plants and their entire ecosystem. The total area of the park is around $2,180 \mathrm{~km}^{2}$ and in 1977, the park was designated as part of the UNESCO World Network of Biosphere Reserves because of the uniqueness of the ecosystem and culture.

The mean annual areal precipitation is approximately $2000 \mathrm{~mm}$ and $70 \%$ of precipitation occurs in rainy seasons, which tends to decrease from the southeast to the northwest and increases along with elevation. The mean annual temperature in this region ranges from $20^{\circ} \mathrm{C}$ to $34^{\circ} \mathrm{C}$. The land use types in the region can mainly be grouped into four categories. Rainforests occupy nearly $82 \%$ of the catchment. The others consist of agricultural land $(9 \%)$, settlement areas $(0.45 \%)$, and other facilities such as open space and water body $(8.5 \%)$. The major soil types in the basin consist of Podsolic, Brown forest soil, Aluvial hidromorf and Litosol which are categorized as fertile land for agricultural, plantation and forest areas.

Due to the pressure of the population in the watershed, there has been intensive land conversion for agriculture, plantations and settlements. The forest conversion has caused a significant change in the hydrological functions, so that it can threaten the dynamic equilibrium of land and environmental resources. The TNLL official reported that more than $1 \%$ of the national forest area has been converted illegally (Lore Lindu National Park-TNLL, 2019). Forest conversion significantly increases the surface flow and land erosion. An increase in the two runoff parameters has caused flooding in the lower reaches, especially in the Palolo Valley, with inundation area reaching more than 1,000 hectares. Flooding in the area have become a major environmental issue that disrupts the agricultural, plantation and settlement areas.

\section{Rainfall and Flow Data}

Rainfall is one of the important meteorological inputs of a hydrologic model (Liu et al., 2017). The data concerning the hourly and daily rainfall as well as the hourly water level were collected from watershed gauging stations for the 10-year 


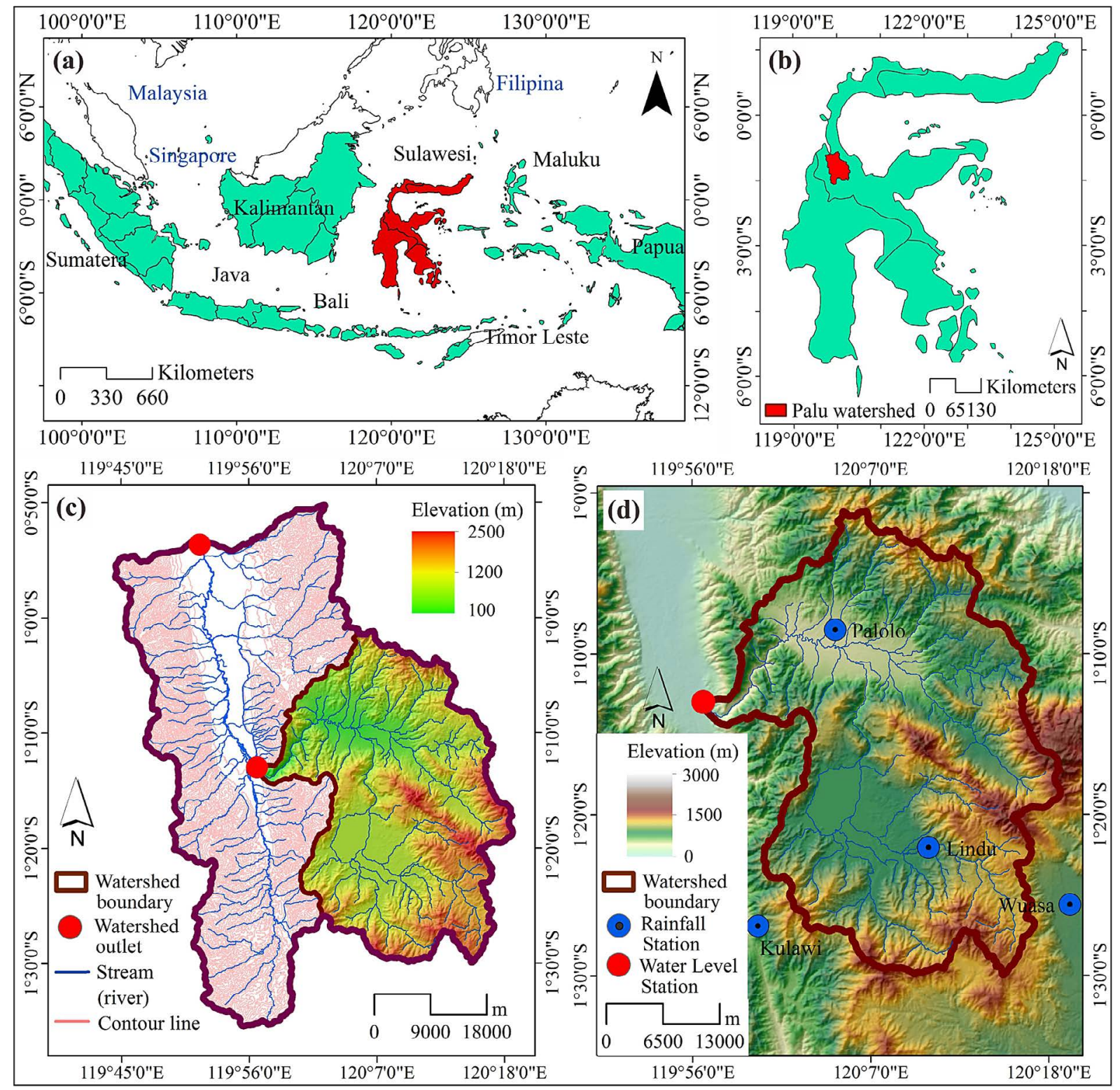

Figure 1. Site description of the study area. (a) Map illustrates Indonesian archipelago where Sulawesi island is the part of the area. b). Sulawesi island. (c). The Palu watershed and its sub-catchments (Gumbasa). (d) Gumbasa sub-watershed illustrated by topographic elevation with the location of hydrologic and hydrometric stations.

period of 2008-2017. The rainfall and streamflow stations were installed by River Basin Board of Sulawesi III and River Basin Management Board of Palu-Poso for managing the water resources in the watershed. The hourly rainfall and streamflow data would be used to derive unit hydrograph, while the daily rainfall data would be analyze to determine the design rainfall for the certain return periods (Kusumastuti et al., 2016). All data that meet the analysis criteria were selected for unit hydrograph derivation and frequency analysis.

\section{Topographic and Land Cover Data}

The topographic data was obtained from Indonesian Geospatial Information Agency-BIG (2019). The data is in the form of $8.25 \mathrm{~m}$-gridded elevation data which is known as DEM Nasional. DEM Nasional was built from several data sources, including IFSAR data (5m resolution), TERRASAR-X (5m resolution) and ALOS PALSAR (11.25m resolution), by adding stereo-plotting masspoint data (Indonesian Geospatial Information Agency-BIG, 2019). This data would be used 
to generate morphometric parameters of watershed, such as drainage properties and catchment area characteristics.

The land use of the watershed could be identified from land cover map accessed from Google Map (2019). This data was used to provide the information on both land use type and density of land cover. It is one of the parameters for determining the flow factor such as a curve number $(\mathrm{CN})$ that is very commonly used in the HEC-HMS model (Halwatura and Najim, 2013; Reshma et al., 2013; Viji et al., 2015; Hassan et al., 2017 and Romali et al., 2017). General information of the land cover can be seen in Figure 2a-b.

\section{Unit Hydrograph}

Sherman (1932) proposed the unit hydrograph theory as a direct runoff hydrograph resulting from one unit of constant intensity uniform rainfall occurring over the entire catchment area (Ghorbani et al., 2013 and Singh et al., 2014). Basically, unit hydrograph is used to learn the relationship between discharge and time at a watershed outlet. Then, this concept is applied to estimate the discharge based on certain rainfall events in a watershed. Unit hydrograph is obtained by dividing the direct runoff hydrograph by its effective rainfall, where the effective rainfall is the rainfall which causes direct runoff expressed by total rainfall minus the part of the rainfall infiltrated into the soil. The derivation of unit hydrograph is illustrated in Figure 3a.

\section{ITS-2 Model}

The ITS-2 Model was proposed by Tunas et al. (2018) using fractal and main morphometric parameters of eight measured watershed in Sulawesi Island. This model is very simple in formula which consists of only one equation for determining the hydrograph curve derived from Gamma Distribution. Three other equations represent the main parameters of the unit hydrograph, that is, peak time, peak discharge and base time. The general form of the unit hydrograph model is dimensionless, which shows the comparison between hydrograph time and peak time as presented in Figure 3b. All equations of the model were expressed as:

$$
q(t)=\left\{\left(\frac{T}{T_{p}}\right) \exp \left(1-\frac{T}{T_{p}}\right)\right\}^{C_{3}}
$$

$$
\begin{gathered}
Q_{p}=\frac{R}{3.6 T_{p}} \frac{A}{A_{S U H}} \\
T_{p}=C_{1}(0.102 L-0.162 \mathrm{D}- \\
\left.-0.524 R_{L}+1.24\right) \\
T_{b}=C_{2}(0.136 \mathrm{~A}-43.0 \mathrm{~S}+11.5)
\end{gathered}
$$

where: $q(t)$ is unit discharge (dimensionless) which represents the equation of unit hydrograph curve.

$C_{1}, C_{2}$, and $C_{3}$ are the coefficient of peak time, the coefficient of base time and the coefficient of hydrograph shape respectively. Three basic parameters of unit hydrograph are $T_{p}, Q_{p}, T_{b}$, which define peak time (hour), peak flow $\left(\mathrm{m}^{3} / \mathrm{s}\right)$ and base time (hour), and respectively.

$L$ is mainstream length (m). $A$ is the area of watershed $\left(\mathrm{km}^{2}\right)$,

$S$ is the slope of the mainstream,

$R$ is unit rainfall ( $\mathrm{mm}$ ),

$A_{S U H}$ is the area under hydrograph curve and $T$ is time (hour).

$D$ and $R_{L}$ may be written with the following equations:

$$
D=\frac{\sum_{\omega}^{\Omega} L_{s}(\omega, \Omega)}{A}
$$

$$
\begin{gathered}
R_{L}(\omega, \Omega)=\frac{\bar{L}(\omega+1, \Omega)}{\bar{L}(\omega, \Omega)} \\
R_{L}=\frac{\sum_{\omega=1}^{\Omega-1} R_{L}(\omega, \Omega)}{\Omega-1}
\end{gathered}
$$

where: $D$ is drainage density $\left(\mathrm{km} / \mathrm{km}^{2}\right)$ and

$R_{L}$ is the ratio of river length (dimensionless).

$\omega$ and $\Omega$ are stream order and highest stream order,

$N$ is the number of stream segment,

$L$ is average stream length $(\mathrm{km})$,

$L_{s}$ is stream length $(\mathrm{km})$ and A is area of watershed $\left(\mathrm{km}^{2}\right)$. 

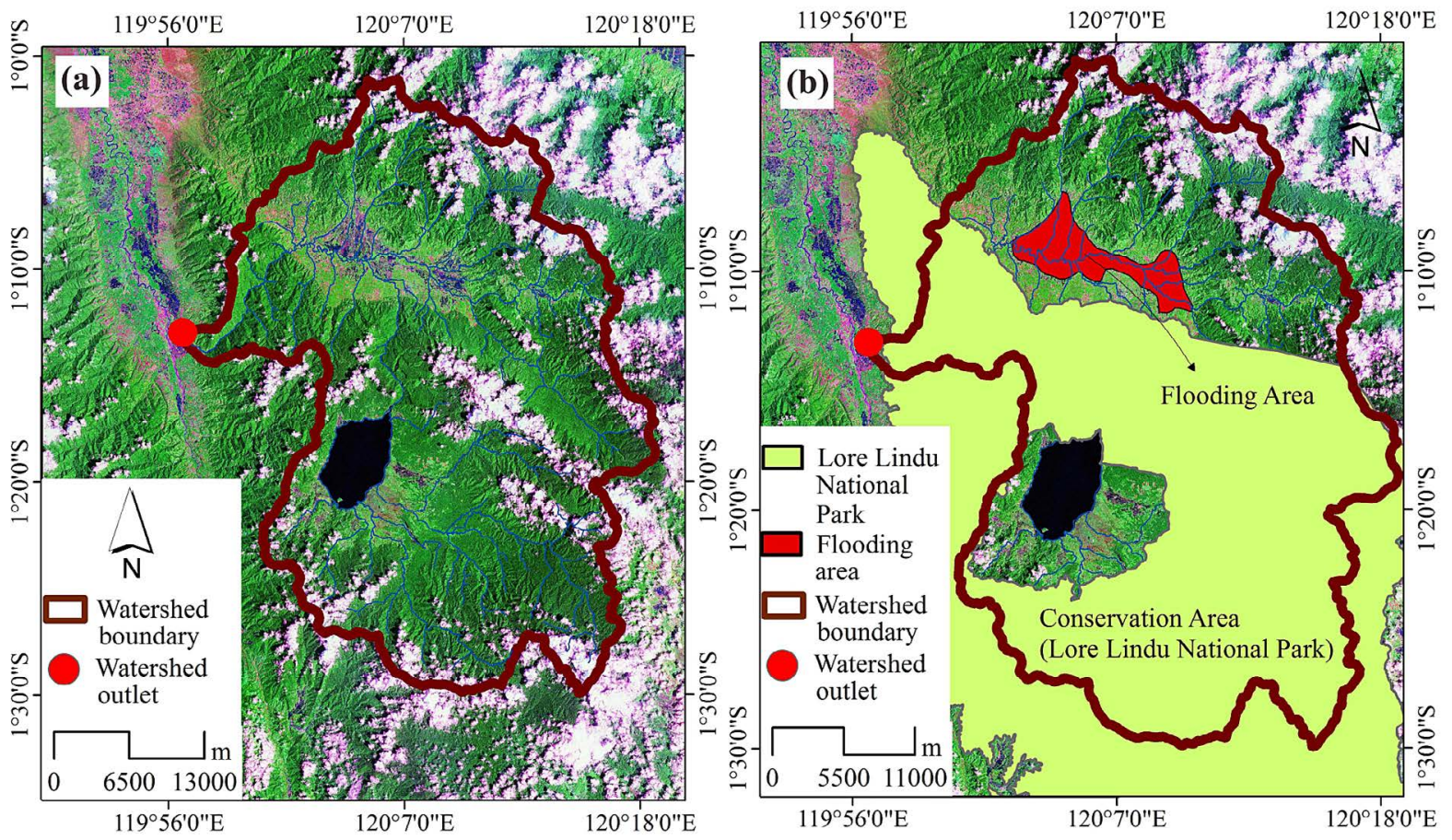

Figure 2. Land use characteristics of the study area. (a) Land cover based on Google map imaginary: the red colour indicates converted land cover to be settlement and open space area, forest and agricultural land are marked by dark and light green, and black colour illustrates water body such as lake, river, pond or other storage areas. (b) The conservation area of Lore Lindu National Park covers more than a half area of Gumbasa sub-watershed (yellow zone) and flooding area around Gumbasa River in the lower segment (red zone).

The reliability of the model can be measured by Nash-Sutcliffe Efficiency (NSE) indicator (Cheng et al., 2013 and Kha et al., 2018), which written as:

$$
N S E=1-\frac{\sum_{i=1}^{n}\left(Q_{i}-\hat{Q}_{i}\right)^{2}}{\sum_{i=1}^{n}\left(Q_{i}-\bar{Q}_{i}\right)^{2}}
$$

where: NSE is Nash-Sutcliffe Efficiency, $\mathrm{n}$ is number of data, $Q_{i}$ is measured discharge $\left(\mathrm{m}^{3} / \mathrm{s}\right), \bar{Q}$ is average measured discharge $\left(\mathrm{m}^{3} / \mathrm{s}\right)$ and $\hat{Q}_{i}$ is computed discharge $\left(\mathrm{m}^{3} / \mathrm{s}\right)$

\section{RESULTS AND DISCUSSION}

\section{Morphometry and Stream Networks}

As mentioned in the previous section, Gumbasa Watershed is included in the large-sized watershed category. Bloschl (1996) defined that the large-sized watershed is a watershed with an area of more than $1000 \mathrm{~km}^{2}$ (Uhlenbrook et al.2004, Safarina 2012). This watershed has an oval shape with a long axis in the North-South direction and the watershed outlet is on the western side. Compared to the area of more than $1000 \mathrm{~km}^{2}$, the length of the main river is relatively short (roughly 91 $\mathrm{km})$. This is related to river network configuration, where watershed outlet is not at the end of the long axis, but at the end of the short axis. In addition, because most watersheds are hilly and mountainous areas, the slope of the main river is relatively very steep $(0.0150)$. Watersheds of this type tend to be prone to erosion, including sheet erosion and groove erosion.

Unlike other common watersheds, the Gumbasa Watershed consists of valleys in the middle of the area. In the upper and lower part of the watershed, the morphology is dominated by hills and mountains. The channel in the upstream and downstream segments is narrower than the middle segment. The shape of the channel in this segment constantly changes depending on the flows. During the rainy season, the generally eroded soil layers in the upper watershed settle in the middle section. As a result of this deposition, the riverbed becomes shallower so that the channel capacity becomes reduced and causes overflow both on the left side and on the right side of the river banks. 


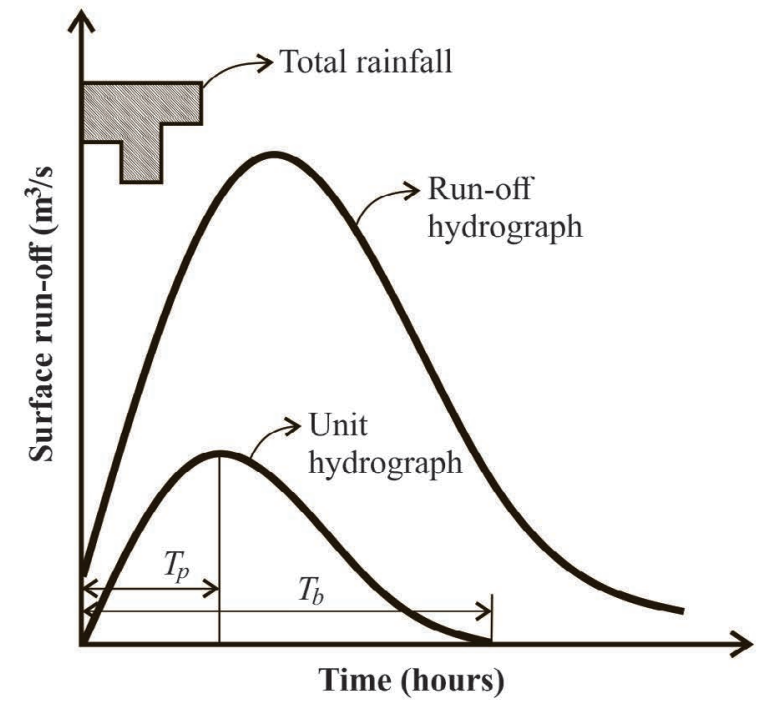

(a)

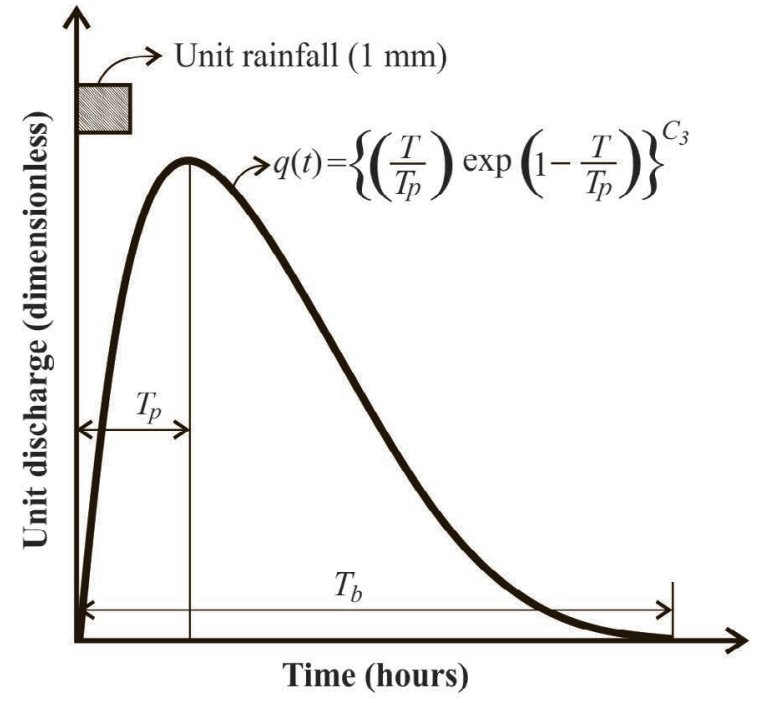

(b)

Figure 3. Typical shape of hydrograph. (a) Unit hydrograph derived from runoff hydrograph. (b) ITS-2 model, unit hydrograph derived from watershed characteristics.

In addition, the slope of the riverbed in this segment is lower than the upstream and downstream segments. The riverbed slope has a positive relationship with flow velocity. If the slope decreases, the flow velocity will decline and have an impact on the weak carrying capacity of the flow. That is the explanation why the middle segment of the watershed, especially in the Palolo Valley is very vulnerable to flooding.

In parts of the valley, the density of stream networks is much lower than in the hills and mountains. The density of stream is closely related to the order of the stream. A watershed with a high stream density has a more complex stream order than a watershed with a low density. In general, the density of the Gumbasa drainage network is included in the low category (less than $2 \mathrm{~km} / \mathrm{km}^{2}$ ) with the number of tributary junction reaching 1900 points (Figure $4 \mathrm{a}$ ), and the drainage consists of six orders (Figure $4 \mathrm{~b}$ ). The ratio of the length of the stream that describes the configuration of the length of the river segment at all levels can be determined based on these parameters (Table 1). Drainage density and junction theoretically have a close relationship with the hydrological process in the watershed. Goni et al. (2019) stated in the results of their research that the density of river networks influences the velocity of streamflow in the watershed. The watersheds with higher stream network densities require shorter time to reach the peak flow and vice versa.

\section{Unit Hydrograph}

Basically, the peak and duration of the flood can be predicted well using a measured unit hydrograph derived from a number of past flood events. The required data includes the pairs of hourly rainfall and single peak flood hydrographs. However, the main problem with this analysis is the limited amount of data due to the lack of rainfall gauges and the discharge installed. In general, hydrological and hydrometric gauges are installed in areas that are truly hydrologically important, such as the watersheds with the use of diverse water resources and strategic areas that must be protected from the danger of flooding. The Gumbasa Watershed has at least two rainfall gauges and one hydrometry measuring device (AWLR). On the basis of the data from the period 2008-2015, fifteen pairs of rainfall-discharge data were selected to derive unit hydrograph. The measured unit hydrograph derived from the data - as shown in Figure 5 - is the average unit hydrograph. The analysis results show that the rising side of the measured unit hydrograph is steeper than the recession side. This means that the peak time is shorter than the time of recession. The form of such hydrograph a typical hydrograph of the rivers in Indonesia in general, where the land use factors and physical properties 


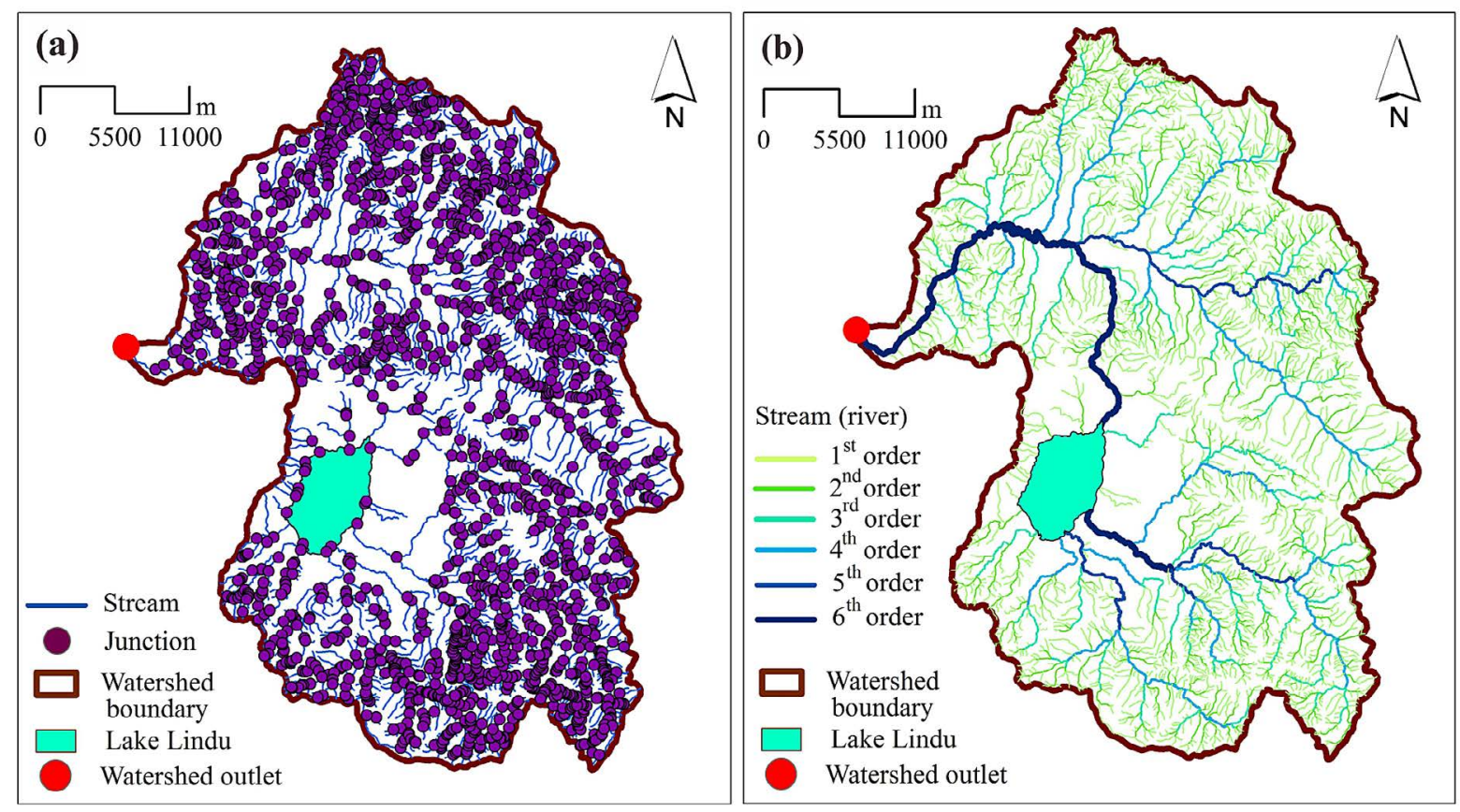

Figure 4. Stream networks of the river basin. (a) Map illustrates the junction of the stream network which represents the bifurcation and the density of drainage basin. (b) Stream order which generated from the junction according to Stahler method.

Table 1. The determination ratio of river length (RL) of the stream network.

\begin{tabular}{|l|c|c|c|c|c|c|}
\hline \multirow{2}{*}{\multicolumn{1}{|c|}{ Parameters }} & \multicolumn{7}{c|}{ Stream order } \\
\cline { 2 - 7 } & 1 & 2 & 3 & 4 & 5 & 6 \\
\hline Number of stream segment $(\mathrm{N})$ & 2163 & 955 & 535 & 291 & 85 & 79 \\
\hline Number of stream length, $\mathrm{km}$ & 1414.28 & 514.76 & 296.03 & 157.33 & 57.74 & 63.04 \\
\hline Average stream length $(L), \mathrm{km}$ & 0.65 & 0.54 & 0.55 & 0.54 & 0.68 & 0.80 \\
\hline Ratio of stream length & 1.21 & 0.97 & 1.02 & 0.80 & 0.85 & \\
\hline Average ratio of stream length $(R L)$ & 0.97 & & & & & \\
\hline
\end{tabular}

of watershed play a role in determining the side of recession and the factor of aquifer storage affects the shape of the recession side.

Synthetic unit hydrographs using the ITS-2 model generated from the watershed parameters as in Eq. (1) - Eq. (4) can be a reference for determining unit hydrographs in other unmeasured rivers around the Gumbasa Watershed. The shape of unit hydrograph, predicted using this model is relatively different from the measured unit hydrograph (Figure 5a before optimization). The difference is seen in the rising side, peak discharge and recession side, where synthetic unit hydrographs have shorter peak times, lower peak discharge and base time longer than measured unit hydrographs. However, if evaluated with an error indicator, the performance of the model is very good (with NSE more than $80 \%$ ), where the coefficient of the parameter uses a standard value $\left(C_{1}=1, C_{2}=1\right.$ and $C_{3}=1$ ). The results of this comparison also provide the information that the parameters need to be optimized to improve its performance. Similarly to the NSE indicator, the correlation coefficient also shows a fairly good performance with r reaching over $70 \%$ (Figure $5 \mathrm{~b}$ ).

Optimization of model parameter coefficients proved to be capable of improving the performance of the ITS-2 Model. The NSE indicator increased from 0.94 to 0.99 (Figure 5a). Likewise, the correlation coefficient increased from 0.97 to 0.99 (Figure 5b). It also shows that optimization is very effective for optimizing the model parameter coefficients. Optimization of the ITS-2 Model has also been done previously by Tunas and Anwar (2018) in Telen Watershed, one of a medium-sized watershed in Borneo Island, Indonesia. The results of the analysis show that the performance of the model increased significantly. Using standard coefficients, the ITS Model also showed good performance with NSE above $80 \%$. This shows 


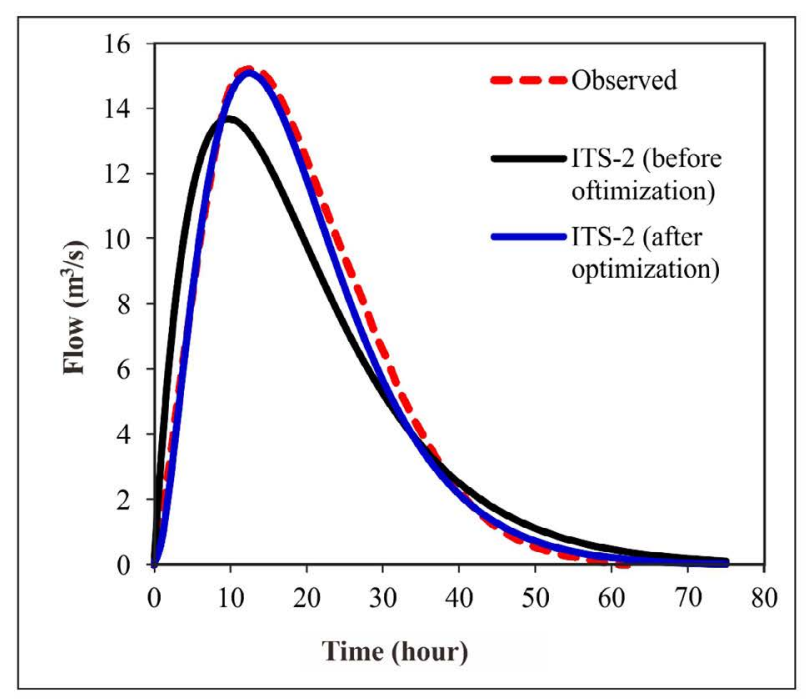

(a)

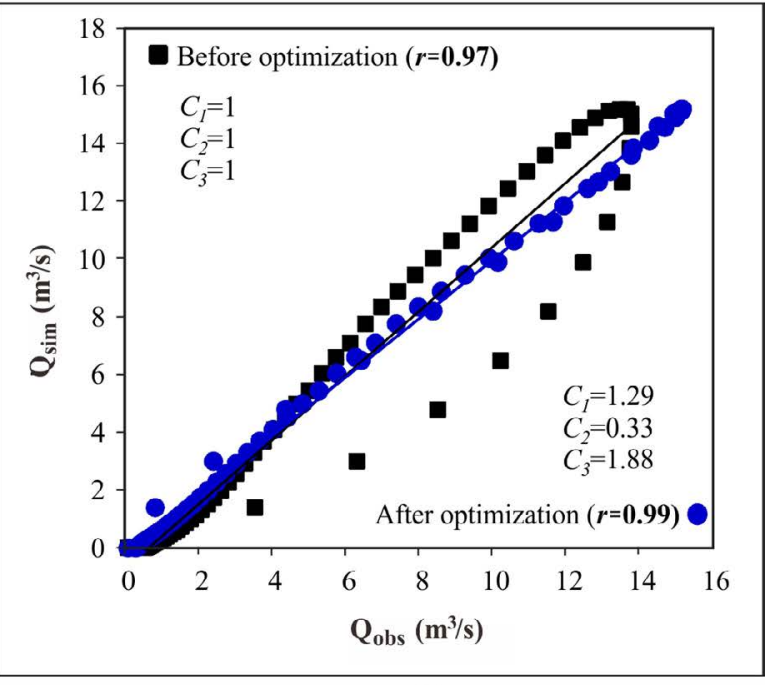

(b)

Figure 5. Unit hydrograph of Gumbasa Watershed using initial parameter coefficients of ITS-2 Model. (a) Comparison of the observed and simulated flow of unit hydrograph. NSE before and after optimization are 0.94 and 0.99 , respectively. (b) Scatter graph showing the simulated flow plotted against the observed flow of unit hydrograph.

that in addition to the medium-sized watershed, the ITS-2 Model also proves good performance in large watersheds.

\section{Comparison with Snyder Unit Hydrograph}

Snyder Unit Hydrograph is one of the unit hydrograph models that is widely applied in various regions, including Indonesia. The popularity of using this model is due to its simplicity in parameters and it is the first developed synthetic unit hydrograph model developed to estimate flood peak (Thapa and Wijesekera, 2017). In addition, the watershed morphometric data used to estimate the parameters is easily obtained. As recommended by Snyder, this model can be applied to various watershed sizes by first adjusting the coefficients and constants of the parameters. The parameter includes three coefficients and constants including coefficients that represent watershed storage $\left(C_{t}\right)$, empirical coefficients associated with time lag $\left(C_{p}\right)$ and constants from time lag (n) (Salami et al., 2017).

The main data needed to determine the unit hydrograph using this model is the area of the watershed, the total length of the mainstream and the length of the mainstream from watershed centroid to outlet. These data can be generated from topographic maps or Digital Elevation Models (DEM) using the geographic information system analysis (Mangan et al., 2019). The ease of obtaining this data is also the main reason why this model is widely used, in addition its good performance. However, many other models were proposed after this model was introduced because they accommodated other important morphometric parameters that significantly affected the shape of the hydrograph such as the main river slope, watershed slope, river network configuration and other watershed properties. Another important reason raised by the researchers in developing a unit hydrograph model is the difference in the concept of deriving unit hydrographs (Roy and Thomas, 2016). In the next period, unit hydrograph was not only derived from the watershed morphometric parameters but also based on analog concepts as proposed by Clark (1945) with the concept of time-area diagram and Nash (1959) with the concept of linear reservoir (Sabzevari, 2017). The changes in parameters and concepts in the derivation of unit hydrographs proposed by the researchers basically only aim to obtain the most optimal model performance.

Unit hydrograph analysis in the Gumbasa Watershed using the Snyder Model shows the performance that is somewhat similar to the ITS-2 Model both before and after optimization. The coefficients and constants used to determine model parameters are based on the range of values recommended by Snyder (Salami et al., 2017 and Permatasari et al., 2017), in this case, the middle values of those coefficients are $1.875\left(C_{t}\right), 1.15\left(C_{p}\right)$ and $0.2(n)$. Using these values, the performance of the Snyder Model is slightly lower than the performance of the ITS-2 Model when measured by NSE indicators (Figure 6a) and correlation coefficients 
(Figure 6b). The two evaluation indicators show that the performance of the Snyder Model is relatively good, but not optimal. The same figure also shows the changes in the performance of the Snyder Model after the coefficients and constants have been optimized. The performance of the model is also very significantly increasing close to the performance of the ITS-2 Model. The results of this analysis at least prove the reliability of the Snyder Model that is often used to estimate peak discharge, especially flood.

\section{Application of ITS-2 Model}

Flood peaks on the Gumbasa River can be determined using the ITS-2 Model based on the corresponding return period. The return period used to calculate flood peaks is determined based on disaster mitigation considerations, with a return period of 2 to 100 years. Mitigation considerations relate to the importance of areas protected from flood hazards, such as settlements, agriculture, industry, trade, transportation and other important facilities (Coleman, 2015). Therefore, in the regions with this category, the estimated peak floods are set with a higher return period (Brunner et al., 2017). Besides, the disaster risk is also a major factor in the determination of flood return periods. The areas with high disaster risk must be protected from flood hazards with a greater return period. However, various other factors such as the type and financing of mitigation programs, can also be references in determining the flood return periods (Tomirotti and Mignosa, 2017).

Gumbasa River as a large river is a strategic river in Central Sulawesi. As one of the upper reaches of the Palu River, this river flow has the potential to threaten important areas in its downstream areas, especially the urban areas located in the lower reaches of the Palu River. As a developing city, Palu is the largest city in Central Sulawesi with a population of more than 300,000 . As a capital city with various supporting facilities and infrastructure, the city has a high risk of various potential disasters, especially floods (Tunas and Maadji, 2018). In the middle section, there are agricultural and plantation areas which are the leading commodities in this area. Considering the importance of this region, the flood control planning as part of a disaster mitigation program must be implemented with the appropriate flood discharge, in this case a return period of 25 to 50 years.

On the basis of these considerations, the return period used as a reference for the flood peak analysis is determined by the return period of this range. However, for the purpose of providing data, this analysis also includes flood determination with other return periods in the range of 2 to 100 years. The results of the flood hydrograph analysis are shown in Table 2 and the peak discharge is shown in Figure 7, where the peak flood is associated with the return period. The time of flood peak shifts backward 0.2 hours when compared to the time of unit hydrograph peak (Table 2). This shift is

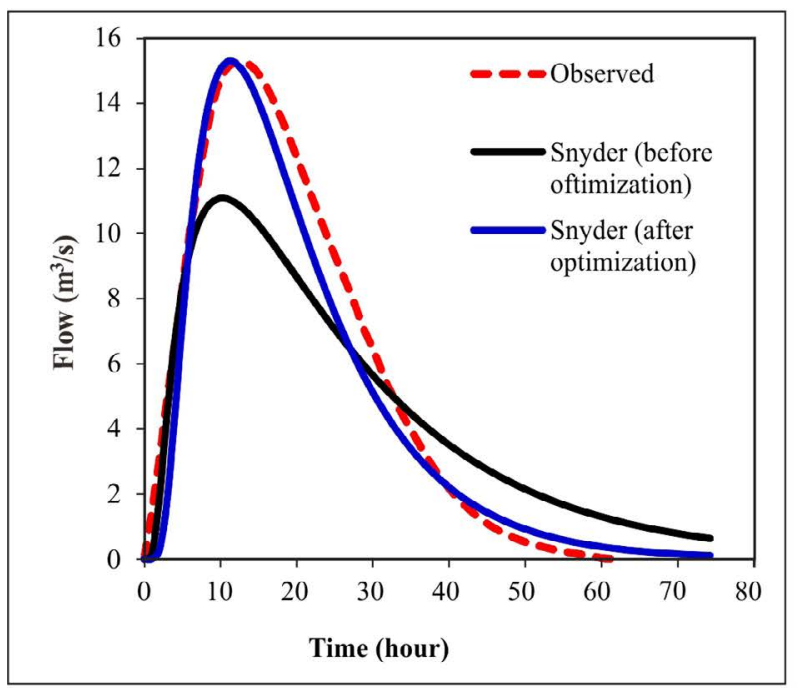

(a)

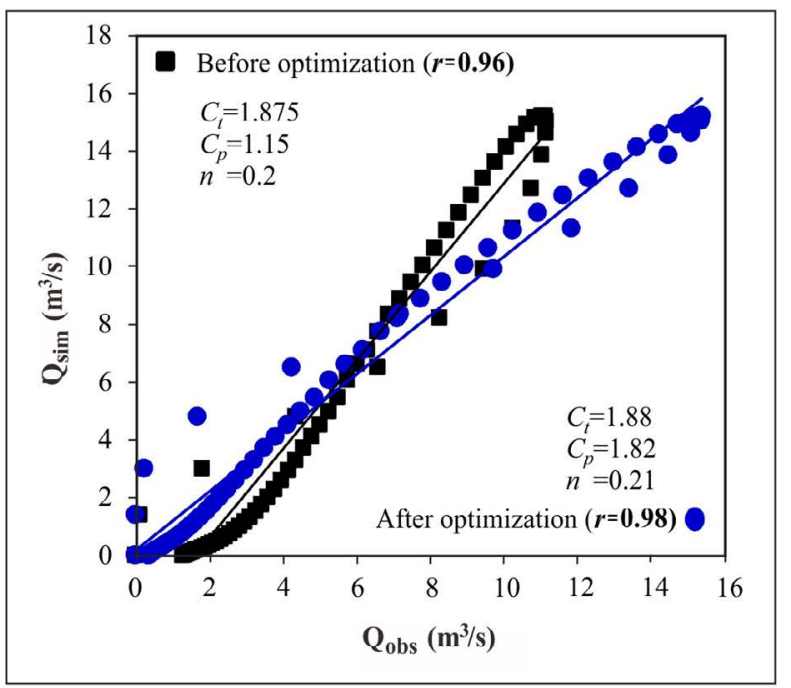

(b)

Figure 6. Unit hydrograph using Snyder Model. (a) Comparison of the observed and simulated flow of unit hydrograph. NSE before and after optimization are 0.86 and 0.98 , respectively. (b) Scatter graph showing the simulated flow plotted against the observed flow of unit hydrograph 
caused by the hourly rainfall convolution process in unit hydrograph to obtain flood hydrograph. The shift of peak time generally occurs at long rainfall duration with the peak of rainfall in the middle or in the end of the duration, depending on the distribution analysis method used (Brunner et al., 2018a and Brunner et al., 2018b). It becomes important to know because peak time can be a reference for an early warning system program (Corral et al., 2019)

The peak of flood, as shown in Figure 7 ranges from $100 \mathrm{~m}^{3} / \mathrm{s}$ to $550 \mathrm{~m}^{3} / \mathrm{s}$ with maximum rainfall in the range of $10 \mathrm{~mm}$ and $100 \mathrm{~mm}$. This amount of rainfall is an effective daily rainfall transformed into hourly rainfall with a duration of 5 hours, where this duration is the dominant duration of rainfall events in the study area which causes flooding in the river. Land cover, soil type and management practices in the watershed are the main factors in determining effective rainfall. The pair of rainfall and flood illustrates that the peak flood discharge in Gumbasa River is included in a large category when compared to the watershed area and the size of the river cross section. The potential of this discharge is not only caused by the maximum rainfall which is the input, it can also be caused by the changes in land use, from forest areas to agricultural, plantation, residential and other areas.

However, when compared with the results of the research conducted by Tunas and Anwar (2018) using a similar model in one of the rivers on the island of Borneo with a watershed area of about half of the Gumbasa Watershed area, the flood discharge with the same return period is far

Table 2. Flood hydrograph of the Gumbasa River with various return periods.

\begin{tabular}{|c|c|c|c|c|c|c|c|c|}
\hline \multirow{2}{*}{$\mathrm{t}$ (hour) } & \multirow{2}{*}{$\begin{array}{c}\text { Unit } \\
\text { hydrograph } \\
\left(\mathrm{m}^{3} / \mathrm{sec}\right)\end{array}$} & \multicolumn{7}{|c|}{ Flood discharge $\left(\mathrm{m}^{3} / \mathrm{sec}\right)$} \\
\hline & & Q1-yr & Q2-yr & Q5-yr & Q10-yr & Q25-yr & Q50-yr & Q100-yr \\
\hline 0 & 0.000 & 3.00 & 3.00 & 3.00 & 3.00 & 3.00 & 3.00 & 3.00 \\
\hline 1 & 0.734 & 6.06 & 7.69 & 9.67 & 11.22 & 12.91 & 15.41 & 17.56 \\
\hline 2 & 2.325 & 13.49 & 19.06 & 25.85 & 31.17 & 36.95 & 45.53 & 52.90 \\
\hline 3 & 4.288 & 23.96 & 35.08 & 48.64 & 59.27 & 70.82 & 87.97 & 102.68 \\
\hline 4 & 6.338 & 36.28 & 53.96 & 75.49 & 92.37 & 110.71 & 137.95 & 161.31 \\
\hline 5 & 8.298 & 49.51 & 74.20 & 104.29 & 127.88 & 153.50 & 191.56 & 224.20 \\
\hline 6 & 10.062 & 62.55 & 94.16 & 132.68 & 162.88 & 195.69 & 244.42 & 286.21 \\
\hline 7 & 11.572 & 74.48 & 112.44 & 158.68 & 194.94 & 234.32 & 292.82 & 342.99 \\
\hline 8 & 12.802 & 84.82 & 128.27 & 181.20 & 222.71 & 267.78 & 334.74 & 392.17 \\
\hline 9 & 13.750 & 93.33 & 141.28 & 199.72 & 245.54 & 295.30 & 369.22 & 432.61 \\
\hline 10 & 14.428 & 99.93 & 151.39 & 214.10 & 263.27 & 316.66 & 395.99 & 464.02 \\
\hline 11 & 14.855 & 104.68 & 158.67 & 224.46 & 276.03 & 332.05 & 415.26 & 486.63 \\
\hline 12 & 15.059 & 107.72 & 163.31 & 231.06 & 284.17 & 341.86 & 427.55 & 501.05 \\
\hline 12.54 & 15.086 & 109.27 & 165.69 & 234.44 & 288.34 & 346.88 & 433.85 & 508.43 \\
\hline 13 & 15.067 & 109.98 & 166.78 & 235.99 & 290.25 & 349.18 & 436.73 & 511.81 \\
\hline 14 & 14.908 & 109.66 & 166.28 & 235.29 & 289.38 & 348.14 & 435.42 & 510.28 \\
\hline 15 & 14.609 & 108.35 & 164.28 & 232.43 & 285.86 & 343.90 & 430.11 & 504.04 \\
\hline 16 & 14.197 & 106.19 & 160.97 & 227.72 & 280.06 & 336.91 & 421.35 & 493.77 \\
\hline 17 & 13.696 & 103.32 & 156.58 & 221.47 & 272.36 & 327.62 & 409.71 & 480.12 \\
\hline 18 & 13.126 & 99.82 & 151.23 & 213.87 & 262.98 & 316.31 & 395.55 & 463.51 \\
\hline 19 & 12.508 & 95.84 & 145.14 & 205.20 & 252.29 & 303.44 & 379.41 & 444.58 \\
\hline 20 & 11.856 & 91.51 & 138.50 & 195.76 & 240.65 & 289.41 & 361.84 & 423.96 \\
\hline 21 & 11.186 & 86.94 & 131.50 & 185.80 & 228.38 & 274.62 & 343.31 & 402.22 \\
\hline 22 & 10.509 & 82.23 & 124.29 & 175.54 & 215.73 & 259.37 & 324.21 & 379.81 \\
\hline 23 & 9.834 & 77.46 & 116.99 & 165.16 & 202.93 & 243.95 & 304.88 & 357.14 \\
\hline 24 & 9.170 & 72.71 & 109.71 & 154.81 & 190.17 & 228.57 & 285.61 & 334.54 \\
\hline$\ldots$ & $\ldots$ & $\ldots$ & $\ldots$ & $\ldots$ & $\ldots$ & $\ldots$ & $\ldots$ & $\ldots$ \\
\hline$\ldots$ & $\ldots$ & $\ldots$ & $\ldots$ & $\ldots$ & $\ldots$ & $\ldots$ & $\ldots$ & $\ldots$ \\
\hline$\ldots$ & $\ldots$ & $\ldots$ & $\ldots$ & $\ldots$ & $\ldots$ & $\ldots$ & $\ldots$ & $\ldots$ \\
\hline 0.048 & 3.39 & 3.59 & 3.84 & 4.04 & 4.25 & 4.57 & 4.84 & 0.048 \\
\hline 0.042 & 3.34 & 3.52 & 3.75 & 3.92 & 4.11 & 4.39 & 4.63 & 0.042 \\
\hline 0.037 & 3.30 & 3.46 & 3.66 & 3.81 & 3.98 & 4.23 & 4.44 & 0.037 \\
\hline
\end{tabular}




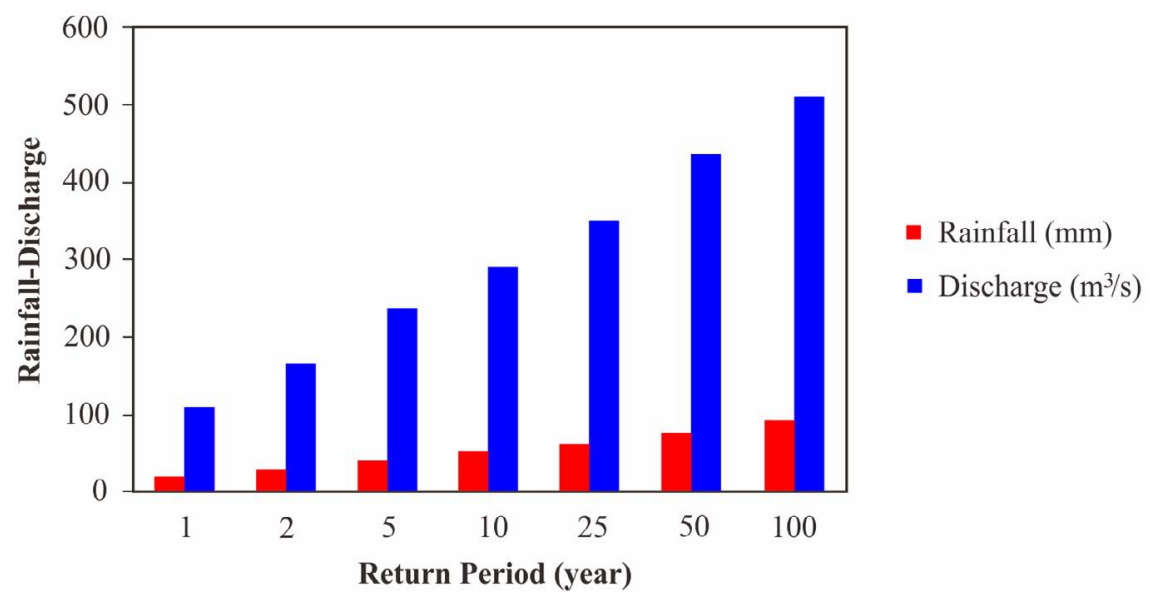

Figure 7. Peak of the flood of the Gumbasa River that correspond to maximum rainfall

greater than the flood discharge in Gumbasa River. As an illustration, the flood discharge with a 100year return period on the river is almost the same as the flood discharge in Gumbasa River with the same return period. The results of the comparison illustrate various factors indicated to have affected the peak of the flood especially rainfall and land use. The massive conversion of forests to palm oil (Elaeis guineensis) and rubber (Hevea brasiliensis) plantations on the island of Borneo has the potential to significantly increase the run-off in most of the rivers in Kalimantan. This factor is thought to be the trigger for the increase in flood disaster in the middle and downstream of the watershed. The documents about flooding from BNPB also state that the flood discharge of rivers on the island of Kalimantan is generally relatively large at present and has increased dramatically (BNPB, 2019).

\section{CONCLUSION}

The use of hydrology models plays an important role in flood disaster mitigation programs, especially in the estimation of peak floods. ITS-2, as one of the flood prediction models based on synthetic unit hydrographs, has been specifically developed to be applied in tropical watersheds, especially in Indonesia. On the basis of a series of previous studies, this model has a very good performance especially for use in small and mediumsized watersheds with an area under $1,000 \mathrm{~km}^{2}$.

The application of this model in a large observed watershed in Indonesia shows that the performance of the model is still very good with NSE above $80 \%$, both before optimization $(\mathrm{NSE}=0.94)$ and after parameter optimization $(\mathrm{NSE}=0.99)$. The performance of this model can also be measured by the correlation coefficient $(r)$ of 0.97 and 0.99 for both conditions, respectively. The value of the coefficient of correlation indicates a very strong relationship between the discharge of observations and predictions. The results of hydrograph analysis using these optimized parameters based on a 1-year to 100year return period indicate that peak flood discharge ranges from $100 \mathrm{~m} 3 / \mathrm{sec}$ to $550 \mathrm{~m}^{3} / \mathrm{sec}$. From a series of analyses and tests that have been conducted in the previous and current research, it can be concluded that the ITS-2 Model can be applied to various watershed sizes, especially in Indonesia.

\section{Acknowledgments}

The authors would like to acknowledge the River Basin Board of Sulawesi III (Ministry of Public Work and Housing, Republic of Indonesia) and River Basin Management Board of Palu-Poso (Ministry of Environment and Forestry, Republic of Indonesia) for kindly providing a large part of rainfall and water level data used in this study. The authors would also like to thank the editor and an anonymous reviewer for their valuable comments which helped improve the manuscript.

\section{REFERENCES}

1. Indonesian National Board for Disaster Management(BNPB). 2019. https://www.bnpb.go.id/berita. Accessed on 25 January 2019. [in Indonesian]

2. Tunas I.G., Anwar N. 2018. A flood forecasting model based on synthetic unit hydrograph of ITS-2. Proc. $20182^{\text {nd }}$ Borneo International Conference on Applied Mathematics and Engineering (BICAME), 2, 42-46. 
3. Tunas I.G., Anwar N., Lasminto U. 2018. A synthetic unit hydrograph model based on fractal characteristics of watersheds. International Journal of River Basin Management, Article in press.

4. Ansori M.B., Tunas I.G., Margini N.F. 2017. Analysis of design flood by considering fractal characteristics of watershed (Case study: Way Apu Dam on Buru Island, Maluku Province). Journal of Hidroteknik, 31, 691-697. [in Indonesian]

5. Leemhuis C., Gerold G. 2006. The impact of the warm phase of ENSO (El Nino Southern Oscillation) events on water resource availability of tropical catchments in Central Sulawesi, Indonesia. Advances in Geosciences, 6, 217-220

6. Leemhuis C., Erasmi S., Twele A., Kreilein H., Oltchev A., Gerold G. 2007. Rainforest conversion in Central Sulawesi, Indonesia: recent development and consequences for river discharge and water resources. Erdkunde, 61(3), 284-293.

7. Gerold G., Leemhuis C. 2008. Effects of ENSOevents and rainforest conversion on river discharge in Central Sulawesi (Indonesia)- problems and solutions with coarse spatial parameter distribution for water balance simulation. Proc. International Congress on Environmental Modelling and Software, $183,553-565$.

8. Lore Lindu National Park (TNLL). 2019. https:// lorelindu.info. Accessed on 2 January 2019. [in Indonesian]

9. Indonesian Geospatial Information Agency (BIG). 2019. http://tides.big.go.id/DEMNAS/. Accessed on 10 January 2019. [in Indonesian]

10. Google Map. 2019. https://www.google.com/ maps/@-1.3197603,120.065525,10209m/ data $=! 3 \mathrm{~m} 1$ ! 1 e. Accessed on 26 January 2019.

11. Uhlenbrook S., Roser S., Tilch Nils. 2004. Hydrological process representation at the meso-scale: the potential of a distributed, conceptual catchment model. Journal of Hydrology, 291, 278-296.

12. Tunas I.G., Maadji R. 2018. The use of GIS and hydrodynamic model for performance evaluation of flood control structure. International Journal on Advanced Science, Engineering and Information Technology, 8(6), 2413-2420.

13. Goni M., Lopez J.J., Gimena F.N. 2019. Geomorphological instantaneous unit hydrograph model with distributed rainfall. Catena, 172, 40-53.

14. Salami A.W., Bilewu S.O., Ibitoye A.B., Ayanshola A.M. 2017. Runoff hydrographs using Snyder and SCS synthetic unit hydrograph methods: A case study of selected rivers in south west Nigeria. Journal of Ecological Engineering, 18(1), 25-34.

15. Permatasari R., Sabar A., Natakusumah D.K. 2017. Determining peak discharge factor using synthetic unit hydrograph modelling (Case study: Upper
Komering South Sumatra, Indonesia). International Journal of GEOMATE, 13(36), 1-5.

16. Akter T., Quevauviller P., Eisenreich S.J., Vaes G. 2018. Impacts of climate and land use changes on flood risk management for the Schijn River, Belgium. Environmental Science and Policy, 89, 163-175.

17. Asdak C., Supian S., Subiyanto. 2018. Watershed management strategies for flood mitigation: A case study of Jakarta's flooding. Weather and Climate Extremes, 21, 117-122.

18. Gao C., He Z., Pan S., Xuan W., Xu, Y.P. 2018. Effects of climate change on peak runoff and flood levels in Qu River Basin, East China. Journal of Hydro-environment Research, Article in press.

19. Safarina A.B. 2012. Modified Nakayasu synthetic unit hydrograph method for meso scale ungauge watersheds. International Journal of Engineering Research and Applications, 2(4), 649-654.

20. Kusumastuti D.I., Jokowinarno D. 2012. Time step issue in unit hydrograph for improving runoff prediction in small catchments. Journal of Water Resource and Protection, 4, 686-693

21. Samu R., Kentel A.S. 2018. An analysis of the flood management and mitigation measures in Zimbabwe for a sustainable future. International Journal of Disaster Risk Reduction, 31, 691-697.

22. Javaheri A., Sebens M.B. 2014. On comparison of peak flow reductions, flood inundation maps, and velocity maps in evaluating effects of restored wetlands on channel flooding. Ecological Engineering, 73, 132-145.

23. Viji R., Prasanna P.R., Ilangovan R. 2015. Modified SCS-CN and Green-Ampt methods in surface runoff modelling for the Kundahpallam watershed, Nilgiris, Western Ghats, India. Proc. International Conference on Water Resources, Coastal and Ocean Engineering, 4, 677-684.

24. Brunda G.S., Nyamathi S. 2015. Derivation and analysis of dimensionless hydrograph and $\mathrm{S}$ curve for cumulative watershed area. Proc. International Conference on Water Resources, Coastal and Ocean Engineering, 4, 964-971.

25. Halwatura D., Najim M.M.M. 2013. Application of the HEC-HMS model for runoff simulation in a tropical catchment. Environmental Modelling \& Software, 46, 155-162.

26. Reshma T., Venkata R.K., Deva P. 2013. Simulation of event based runoff using HEC-HMS model for an experimental watershed. International Journal of Hydraulic Engineering, 2(2), 28-33.

27. Hassan A.K.M.B., Heather M., Jarrett P., Amine M. 2017. Application of HEC-HMS in a cold region watershed and use of RADARSAT-2 soil moisture in initializing the model. Hydrology, 4(9), 1-19. 
28. Romali N.S., Yusop S., Ismail A.Z. 2017. Hydrological modelling using HEC-HMS for flood risk assessment of Segamat Town, Malaysia. Proc. IOP Conf. Series: Materials Science and Engineering, 318, 1-6.

29. Brunner M.I., Seibert J., Favre A.C.. 2018a. Representative sets of design hydrographs for ungauged catchments: A regional approach using probabilistic region memberships. Advances in Water Resources, 112, 235-244.

30. Brunner M.I., Viviroli D., Furrer D., Seibert J., Favre A.C. 2018b. Identification of flood reactivity regions via the functional clustering of hydrographs. Water Resources Research, 54(3), 1852-1867.

31. Thapa G., Wijesekera N.T.S. 2017. Computation and optimization of Snyder's synthetic unit hydrograph parameters. Journal of Water Resource and Protection, 83-88.

32. Kusumastuti D.I., Jokowinarno D., van Rafi'i, C.H., Yuniarti, F. 2016. Analysis of rainfall characteristics for flood estimation in Way Awi watershed. Civil Engineering Dimension, 18(1), 31-37.

33. Cheng C., Cheng S., Wen J., Lee J. 2013. Time and flow characteristics of component hydrographs related to rainfall-stream flow observations. Journal of Hydrologic Engineering, 18(6), 675-688.

34. Gao J., Holden J., Kirkby M. 2016. The impact of land-cover change on flood peaks in peatland basins. Water Resources Research, 52, 3477-3492.

35. Ghorbani M.A., Kashani M.H., Zeynali S. 2013. Development of synthetic unit hydrograph using probability model. Research in Civil and Environmental Engineering, 1, 54-66.

36. Singh P.K., Mishra S.K., Jain M.K. 2014. A review of the synthetic unit hydrograph: from the empirical UH to advanced geomorphological methods. Hydrological Sciences Journal, 59(2), 239-26.

37. Coleman N.M. 2015. Hydrographs of a Martian flood from the breach of Galilaei Crater. Geomorphology, 236, 90-108.

38. Brunner M.I., Viviroli D., Sikorska A.E., Olivier. 2017. Flood type specific construction of synthetic design hydrographs. Water Resources Research, 53(2), 1390-1406.

39. Tomirotti M., Mignosa P. 2017. A methodology to derive synthetic design hydrographs for river flood management. Journal of Hydrology, 555, 736-743.

40. Liu X., Yang T., Hsu K., Liu C., Sorooshian S. 2017.
Evaluating the streamflow simulation capability of PERSIANN-CDR daily rainfall products in two river basins on the Tibetan Plateau. Hydrolology Earth System Science, 21, 169-181.

41. Matteo M.D., Liang R., Maier H.R., Thyer M.A., Simpson A.R., Dandy G.C., Ernst B. 2019. Controlling rainwater storage as a system: An opportunity to reduce urban flood peaks for rare, long duration storms. Environmental Modelling and Software, 111, 34-41.

42. Kha D.D., Nhu N.Y., Anh T.N. 2018. An approach for flow forecasting in ungauged catchments - A Case study for Ho Ho reservoir catchment, Ngan Sau river, Central Vietnam. Journal of Ecological Engineering, 19(3), 74-79.

43. Grimaldi S., Petroselli A., Nardi F. 2012. A parsimonious geomorphological unit hydrograph for rainfall-runoff modelling in small ungauged basins. Hydrological Sciences Journal, 57(1), 73-83.

44. Li J., Chen Y., Wang H., Qin J., Li, Chiao S. 2017. Extending flood forecasting lead time in a large watershed by coupling WRF QPF with a distributed hydrological model. Hydrolology Earth System Science, 21, 1279-1294.

45. Chen Y., Li Y., Wang H., Qin J., Dong L. 2017. Large-watershed flood forecasting with high-resolution distributed hydrological model. Hydrolology Earth System Science, 21, 735-749.

46. Huang K., Chen L., Zhou J., Zhang J., Singh V.P. 2018. Flood hydrograph coincidence analysis for mainstream and its tributaries. Journal of Hydrology, 565, 341-353.

47. Mangan P., Haq M.A., Baral P. 2019. Morphometric analysis of watershed using remote sensing and GIS-a case study of Nanganji River Basin in Tamil Nadu, India. Arabian Journal of Geosciences, 12(202), 1-14.

48. Sabzevari T. 2017. Runoff prediction in ungauged catchments using the gamma dimensionless timearea method. Arabian Journal of Geosciences, 10(131), 1-11.

49. Corral C., Berenguer M., Torres D.S., Poletti P., Silvestro F., Rebora N. 2019. Comparison of two early warning systems for regional flash flood hazard forecasting. Journal of Hydrology, 572, 603-619.

50. Roy A., Thomas R. 2016. A comparative study on the derivation of unit hydrograph for Bharathapuzha River Basin. Procedia Technology, 24, 62-69. 